\title{
Habitat Requirements of the Golden-cheeked Warbler: Management Implications
}

\author{
JAMES C. KROLL
}

\begin{abstract}
Characteristics of nesting and wintering habitats of goldencheeked warblers (Dendroica chrysoparia) were studied from 1973-1978. Golden-cheeks are obligatively dependent on Ashe juniper (Juniperus ashei) for nesting materials and singing perches, but are equally dependent on scrub-oak (Quercus durandii breviloba) for foraging substrates. Golden-cheeks preferred to forage (73.6\% of total observations) in hardwood species. Stepwise discriminant analysis suggested that quality nesting habitat differs from poor nesting habitat by having older $(\geq \mathbf{4 0}$ yrs.) Ashe juniper, lower juniper densities and higher densities of oak (juniper-oak ratio $=1.35$ to 1 ). Structure of scrub-oak (mostly $Q$. oleoides) in the wintering habitat (La Esperanza, Intibuca Dept., Honduras) was structurally similar to that in the nesting habitat. Golden-cheeks were observed feeding in the shrubby understory.
\end{abstract}

The golden-cheeked warbler (Dendroica chrysoparia) is a rare bird inhabiting the so-called "cedar brakes" in the Edwards Plateau region of west-central Texas. Golden-cheeks have been the center of controversy involving clearing of Ashe juniper (Juniperus ashei) for range improvement and commercial harvesting for fence posts and aromatic oils; yet, no study to date has dealt quantitatively with habitat requirements of these birds.

Pulich (1976) conducted an in-depth study on the natural history of golden-cheeks. He noted that the warblers are obligatively dependent on Ashe juniper for nesting habitat, and that golden-cheeks require large blocks of mature ( $\geq 50$ years old) Ashe juniper. He further noted that: "Only older cedar brakes with some variation in age provide the necessary requisites of warbler habitat.' 'Previous studies by Johnston et al. (1952) and Huss (1954) characterized the vegetative composition of golden-cheek nesting habitat as juniper-oak; juniper composition ranged $14-50 \%$ (of stems per acre), while oaks made up 20-70\%.

My study was initiated to obtain quantitative data on nesting and wintering habitats of golden-cheeks, as well as, to develop a habitat management strategy for these rare birds.

\section{Methods}

\section{Meridian State Park Study Area}

Meridian State Park is located in Bosque County, approximately 83 $\mathrm{km}$ west of Waco, Tex. (Fig. 1). The park contains 203.2 ha, about one fourth of which is inundated by Lake Bosque. The eastern portion (=Area I) of the Park has been developed to accommodate over-

\footnotetext{
The author is associate professor of forest wildlife, School of Forestry, Stephen F Austin State University, Nacogdoches, Texas 75962.

The study was supported in part by the U.S. Fish and Wildlife Service. The author wishes to thank R.D. Montgomery, J.R. Martin, and R.N. Davis for help in collecting field data.

Manuscript received October 5, 1978.
}

night campers and picnickers; while the western portion (=Area II) remains relatively undeveloped as a hiking and "wilderness" area. Limited habitat management (viz., thinning and limbing of juniper) for golden-cheeks has been attempted by the Texas Parks and Wildlife Department in Area II.

Vegetation is dominated by juniper-oak, with some riparian habitat occurring along tributaries of Lake Bosque. Soils are predominately shallow, well-drained calcareous clays, with numerous outcrops of limestone. The area contains considerable topographic diversity typical of the Edwards Plateau Region; elevation averages 1,000 m.

\section{Aging of Ashe J uniper}

In 1973, six study areas were selected for aging studies of Ashe juniper (Fig. 1). Study areas included previously defined (Pulich, pers. comm.) golden-cheek nesting habitat in Area II. Increment cores were taken from 60 randomly selected Ashe junipers (ten in each area) at $60 \mathrm{~cm}$ (above ground surface), stored in plastic soda straws, and returned to the laboratory for processing. Tree height, diameter and the degree of bark sloughing (top and bottom) were noted for each tree. In the laboratory cores were dried at $100^{\circ} \mathrm{C}$ and X-rayed. X-ray films (Fig. 2) of increment cores were analyzed using a Densicord Electrophoresis Densitometer (Photovolt Corp.). Annual rings were then counted from densitometer tracings.

\section{Golden-cheek Nesting Habitat}

A census of golden-cheeks was conducted each nesting season (March-July) during the period 1974-78. Home ranges of warblers were determined (Kroll and Davis, unpubl.) by following birds and marking each tree utilized with a numbered tag. Tree species utilized and the birds' behavior were recorded.

\section{Meridian State Recreation Area}

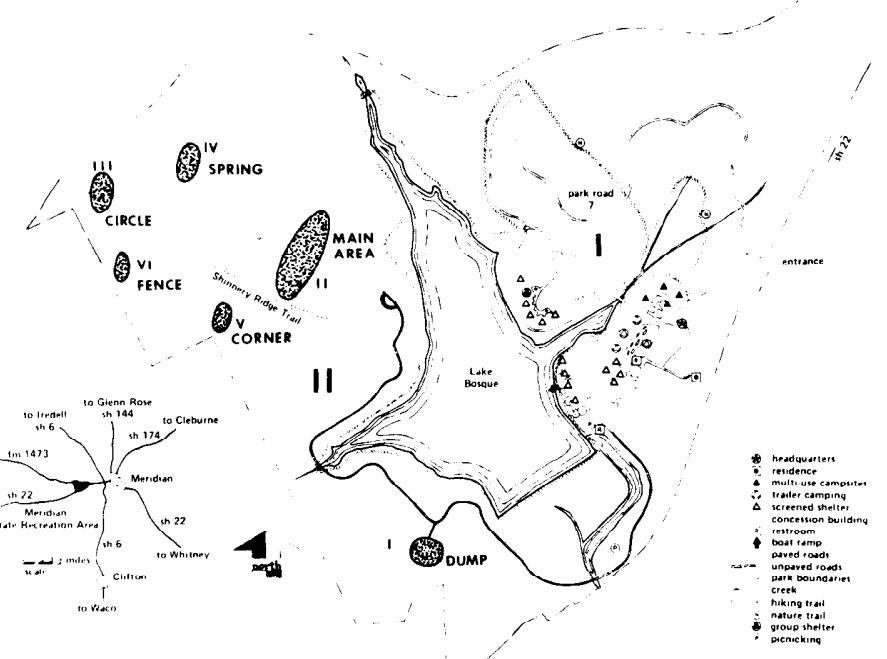

Fig. 1. Meridian State Recreation Study Area near Meridian, Tex., showing the six areas in which aging studies were conducted. 


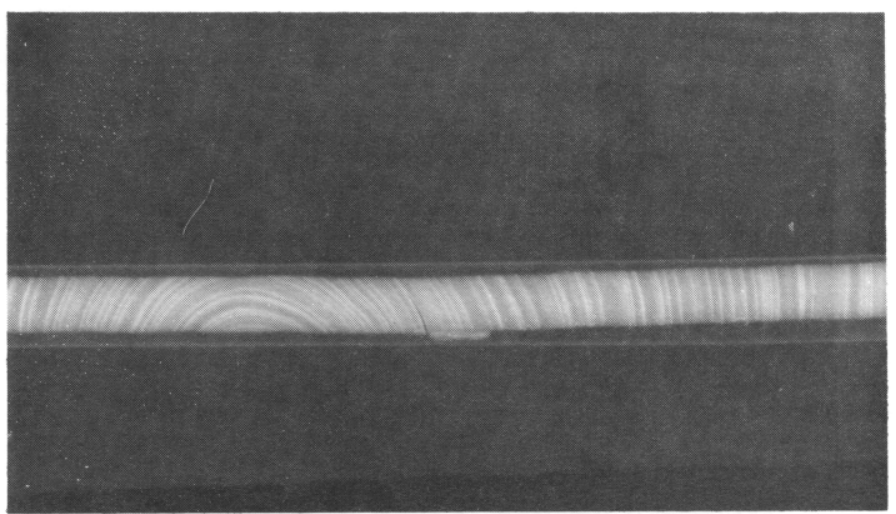

Fig. 2. X-ray of increment core of Ashe juniper showing illumination of annual rings. X-ray films were subsequently analyzed with a densitometer.

Areas within home ranges (Fig. 3) of golden-cheeks were classified as "good" habitat, while areas not utilized by the birds during the 5 -year study period were designated as " poor" habitat. Two hundred sample points each were randomly distributed within good and poor habitats. Point centered-quarter measurements (Cottam and Curtis 1956) were taken at each sample point. In addition, :1-hectare plots
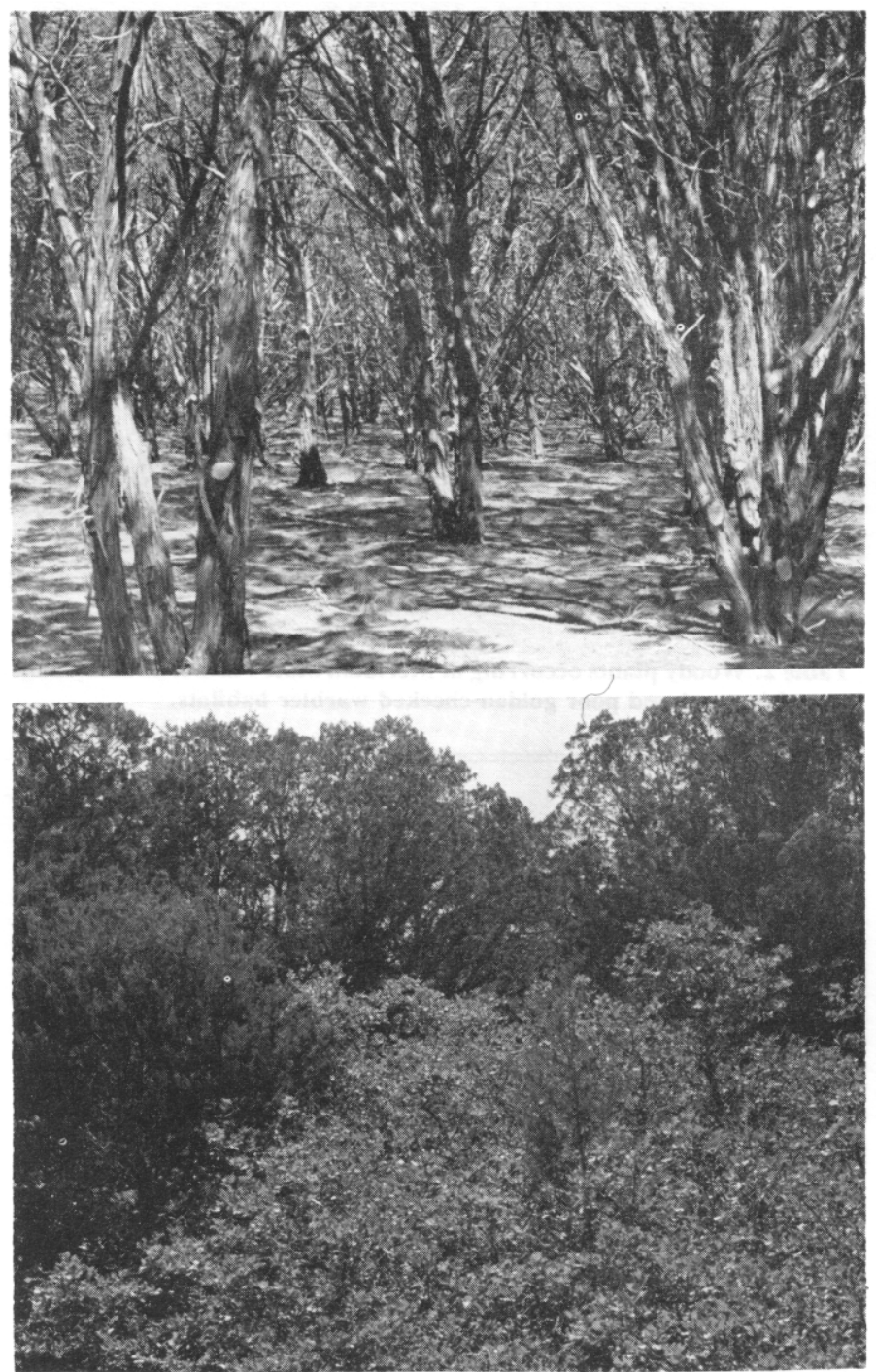

Fig. 3. Above, area of pure Ashe juniper in which limited thinning and limbing has been conducted by the Texas Parks and Wildlife Department. Below. primary Golden-cheek nesting area consisting of mixed oak-juniper. were established using the point-quarter sample point as the center. Measurements included densities of juniper and oaks, tree heights (m).

\section{La Esperanza Study Area}

Monroe (1968) reported 7 specimens from Honduras; 3 (2 males and 1 female) at La Esperanza; 2 (male and female) at Cantoral; and a single specimen from Cerro Cantoral. In March 1975, an intensive search was initiated to locate golden-cheeks in their wintering habitats at La Esperanza (Intibuca Dept.). I observed 12 golden-cheeks feeding with black-throated green warblers (Dendroica virens) $4.1 \mathrm{~km} \mathrm{SW}$ of La Esperanza. This region of Honduras is characterized by highland pine and pine-oak (Fig. 4), designated respectively as ocotol and falda encinal-robledal by Carr (1950). The pine-oak association is restricted in Honduras (Monroe, 1968), occurring only in scattered stands within the highland pine type. Climate is dry and cool (Wise 1958), soils acidic and terrain steep.

Since the birds were transitory and limited time was available, I did not attempt to define areas not utilized by the birds. Hence, I established 20 :1-hectare plots within the area utilized by goldencheeks. Tree species present, densities of pines and oaks (stems/ha), tree heights and diameters, tree age, basal areas $\left(\mathrm{m}^{2} / \mathrm{ha}\right)$, and overstory closures $(0-100 \%)$ were recorded at each plot.

\section{Statistical Analyses}

Relationships between ages of Ashe juniper to diameters were examined using simple linear regression $(Y=A+B X)$, while heightdiameter relationships were determined by nonlinear regression $\left(Y=A X^{b}\right)$

Univariate (Oneway Analysis of Variance) and multivariate (Discriminant Analysis) comparisons of data from good and poor golden-cheek nesting habitats were made using the "Statistical Package for the Social Sciences" (Nie et al. 1970).

The 0.05 level of acceptance was used throughout this study.

\section{Results}

Age of Ashe Juniper Nesting Habitat

Mean ages of Ashe juniper within the six study plots are presented in Table 1. Oldest and tallest trees were in the Main Area (cf., Fig. 1); while the youngest were in the Spring Area. Mean age for all study plots was $40.8 \pm 29.4$ years. This figure was checked against U.S. Dep. Agr. Soil Conservation Service (Temple, Tex.) information about the area prior to its becoming a state park; the area was mostly devoid of junipers about 41 years prior to the aging study (L. Post, pers. comm.)

Regression analyses were conducted on data in order to determine relationships for age vs. diameter and diameter vs. height (Fig. $5 \& 6$ ). ${ }^{1}$ There was a significant linear relationship $(r=0.867 ; Y=0.875+0.347 X)$ between diameter and age for the limits 10-100 years. Further analysis suggested a significant curvilinear relationship for height and diameter $\left(r=0.864 ; Y=1.67 X^{0.572}\right)$.

I applied the above regression model to data obtained from .1-hectare plots in order to estimate age distribution within nesting areas: $86.4 \%$ of junipers were estimated to be no more than 50 years old (Fig. 7).

Since the birds use the sloughed bark of Ashe juniper as the major nest component (Pulich 1976), I also determined ages at which trees slough bark at their bases and crowns. Trees began sloughing bark near the base by 20 years and at the crown by 40 years. Female golden-cheeks were observed pulling bark from both tree regions, but more often from the main trunk near the base.

'Trees judged to be less than 10 years old were not included in this analysis, but were included in the general category "seedling. 

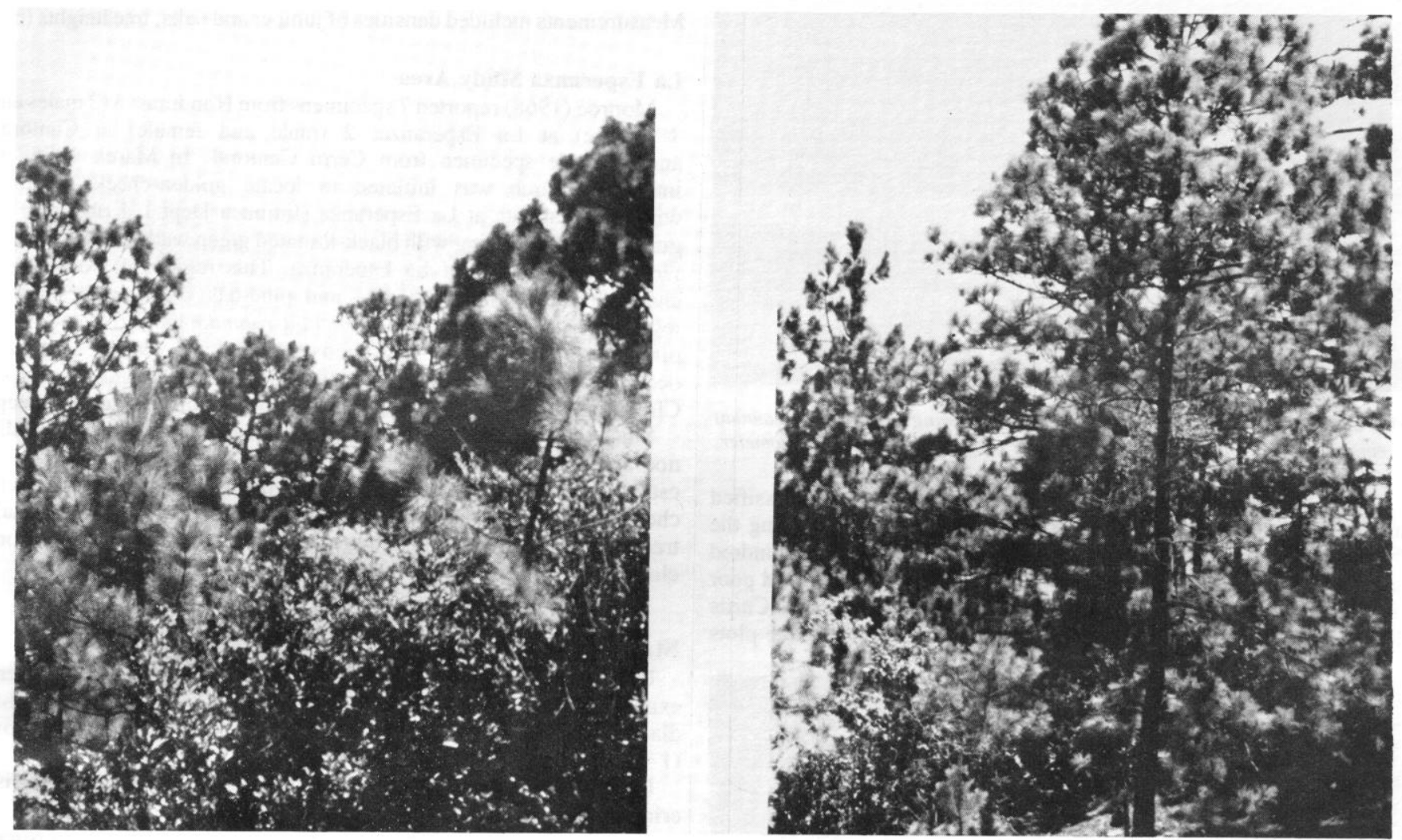

Fig. 4. Left, upland mixed pine-oak habitat near La Esperanza, Honduras. Right, pure pine habitat near Tegucigalpa, Honduras.

Analysis of Nesting Habitat

Golden-cheeks were previously thought to occupy only restricted areas in the western portion of the park (cf., Fig. 1); however, birds were distributed throughout Areas I \& II (Fig. 8).

The golden-cheeked warbler appears to be a typical edge species. Home ranges were situated adjacent to roads, clearings, and trails. Published estimates of territory size range from 2 acres (0.81 ha) per pair (Pulich 1962) to 6.3 acres $(2.55$ ha) per pair (Pulich 1976), with rate of occurrence being one pair per 30 acres ( $12.15 \mathrm{ha}$ ) of suitable habitat. I estimated rates of occurrence for Meridian State Park to range 4.49-8.48 ha $(n=10)$ per pair, higher than the estimates of Pulich $(1962$, 1976).

\section{Comparisons of Good and Poor Habitats}

Since the golden-cheek population of Meridian State Park seemed relatively stable (cf., Fig. 8), I considered areas consistently included within territories during each year of the study as good golden-cheek habitat. Areas in which the birds were conspicuously absent were classified as poor habitat. To the casual observer, good and poor habitats seemed quite

Table 1. Mean ages of Ashe juniper used as nesting habitat by goldencheeked warblers at Meridian State Park, Tex.

\begin{tabular}{lcc}
\hline Area & Mean height $(\mathrm{m})$ & Mean age $(\mathrm{yrs})$. \\
\hline Dump & 5.00 & 45.0 \\
Main & 5.94 & 56.3 \\
Circle & 4.05 & 36.0 \\
Spring & 3.75 & 29.2 \\
Corner & 3.63 & 39.1 \\
Fence & 3.93 & 39.2 \\
\hline
\end{tabular}

similar; yet on closer examination, there were considerable differences. Golden-cheeks preferred sites which could only be considered a suboptimum for plant growth; that is, certain edaphic features (viz., xeric sites with shallow, rocky soils) limited woody plant growth. Golden-cheek habitat had less Ashe juniper and more Bigelow oak (Quercus durandii breviloba) than poor habitat (Table 2). Juniper-oak ratios for good

Table 2. Woody plants occurring at Meridian State Park in all study plots, and in good and poor golden-cheeked warbler habitats.

\begin{tabular}{lccc}
\hline \multirow{2}{*}{ Plant species } & \multicolumn{3}{c}{ Relative abundance ${ }^{1}(\%)$} \\
\cline { 2 - 4 } & All plots & Good habitat & Poor habitat \\
\hline Juniperus ashei & 53.4 & 51.6 & 54.6 \\
Quercus durandii & 21.4 & 32.5 & 16.4 \\
$\quad$ breviloba & & & \\
Quercus texana & 5.4 & 4.8 & 5.7 \\
Fraxinus texensis & 4.4 & 3.2 & 5.0 \\
Forestiera pubescens & 3.4 & 2.4 & 3.9 \\
Ulmus crassifolia & 2.5 & - & 3.6 \\
Rhus toxicodendron & 2.5 & 1.6 & 2.9 \\
Quercusfusiforma & 1.5 & 0.8 & 1.8 \\
Rhus copallina lanceolata & 1.2 & - & 1.1 \\
Cercis canadensis & 0.7 & 0.8 & 0.7 \\
Smilax sp. & 0.7 & 0.8 & 0.7 \\
Rhus aromatica & 0.7 & - & 1.1 \\
$\quad$ flabelliformis & & & \\
Viburnum rufidulum & 0.7 & - & 1.1 \\
Sophora affihris & 0.2 & - & 0.4 \\
Legume & 0.2 & - & 0.4 \\
Ilexdecidua & 0.2 & - & 0.4 \\
Sapindus drummondii & 0.2 & - & 0.4 \\
Bumelia lannginosa & 0.2 & - & 0.4 \\
\hline
\end{tabular}

Determined from point-quarter analyses. 
Table 3. Habitat variables measured in good and poor golden-cheeked warbler habitats.

\begin{tabular}{|c|c|c|}
\hline \multirow{3}{*}{$\frac{\text { Variable }}{\text { Age of Ashe iuniner }}$} & \multicolumn{2}{|c|}{ Mean values ( \pm S.E.) } \\
\hline & Good habitat & Poor habitat \\
\hline & $47.35 \pm 21.28$ & $25.64 \pm 2.04$ \\
\hline $\begin{array}{l}\text { Distance }(m) \text { between } \\
\text { trees }\end{array}$ & $2.77 \pm \quad 0.19$ & $2.32 \pm 0.13$ \\
\hline $\begin{array}{l}\text { Distance between } \\
\text { Ashe juniper trees }\end{array}$ & $3.37 \pm 2.68$ & $2.86 \pm 1.92^{* 1}$ \\
\hline Diameter $(\mathrm{cm})$ of all trees & $18.47 \pm 7.91$ & $10.31 \pm 0.68$ \\
\hline Diameter of Ashe juniper & $32.07 \pm 15.18$ & $15.42 \pm 1.02$ \\
\hline Diameter of Bigelow oak & $3.13 \pm 0.47$ & $2.83 \pm 0.39$ \\
\hline $\begin{array}{l}\text { Density (stems/ha) } \\
\text { for all trees }\end{array}$ & $987.7 \pm 124.18$ & $1196.83 \pm 145.94$ \\
\hline Density of Ashe juniper & $746.49 \pm 121.24$ & $824.44 \pm 139.67$ \\
\hline Density of Bigelow oak & $203.23 \pm 57.70$ & $139.75 \pm 40.66$ \\
\hline Height (m) of all trees & $3.39 \pm 0.19$ & $6.15 \pm 0.97$ \\
\hline Height of Ashe juniper & $4.55 \pm 0.22$ & $6.05 \pm 1.09$ \\
\hline Height of Bigelow oak & $1.76 \pm 0.23$ & $5.77 \pm 2.99$ \\
\hline
\end{tabular}

1* Significantly different at 0.05 .

and poor habitats were 1.35 to 1 and 2.27 to 1 , respectively. Bigelow oak, a dwarfed, thicket-forming shrubby oak characteristic of dry limestone outcrops, was the most abundant oak species in Meridian. Further comparisons of 12 variables (Table 3 measured in the two habitat types suggested that goldencheek nesting habitat contained older Ashe junipers, occurring at wider spacings and lower densities.

In order to obtain a measure of habitat diversity, I calculated diversity index values using standard information theory (Shannon and Weaver 1963). Surprisingly, variables for good habitats were less diverse than those for poor habitats (Table 4). The only exceptions to this trend were height and diameter of Bigelow oak.

Table 4. Diversity of habitat variables measured in good and poor goldencheeked warbler habitats.

\begin{tabular}{lcc}
\hline \hline & \multicolumn{2}{c}{ Diversity index } \\
\cline { 2 - 3 } Variable & Good habitat & Poor habitat \\
\hline Woody plant species & 1.297 & 1.678 \\
Age of Ashe juniper & 2.517 & 3.041 \\
Heights for all trees & 3.185 & 3.325 \\
Heights of Ashe juniper & 2.887 & 3.134 \\
Heights of Bigelow oak & 2.707 & 2.656 \\
Diameters of all trees & 3.860 & 3.859 \\
Diameters of Ashe juniper & 3.537 & 4.332 \\
Diameters of Bigelow oak & 2.919 & 2.889 \\
\hline
\end{tabular}

A stepwise discriminant function analysis (DFA) was performed on data for 12 habitat variables. DFA for good and poor golden-cheek habitats was highly significant $(P<.001)$; significance refers to the analysis' capability to discriminate

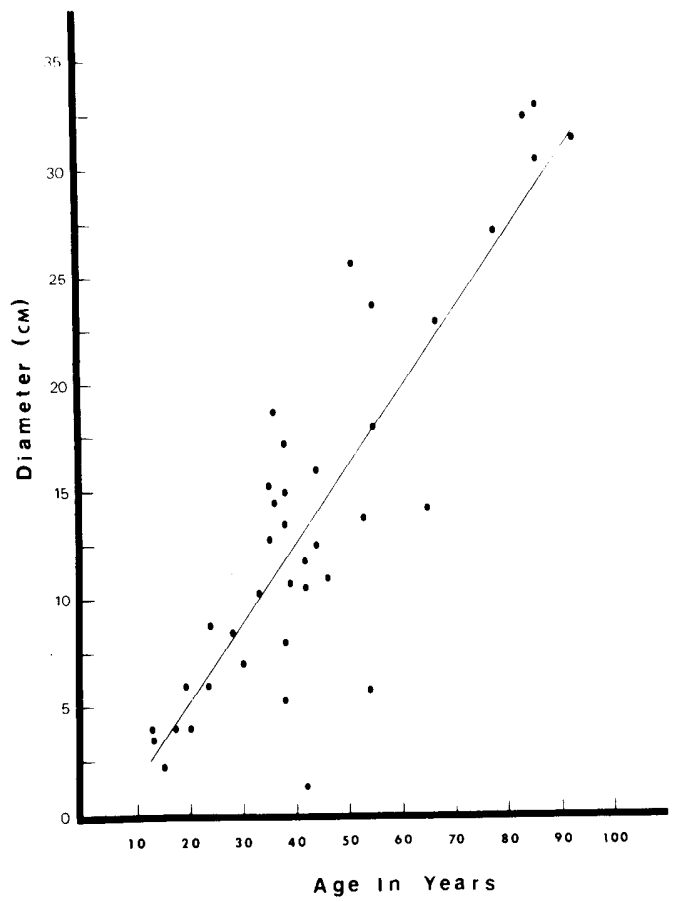

Fig. 5. Relationship between diameter of Ashe juniper to age. $(\mathbf{r}=0.867$; $\mathrm{Y}=0.875+0.374 \mathrm{X}$ )

between the two data sets. Variables included were: presence or absence of Bigelow oak; distance $(\mathrm{m})$ between juniper; density (stems/ha) of Bigelow oak; density of Ashe juniper; height (m) of stand; age of Ashe juniper; and presence or absence of Ashe juniper. Significance values for these variables are presented in Table 5. The absolute value of each coefficient reflects relative

Table 6. Vegetation substrates used by golden-cheeked warblers for singing and foraging.

\begin{tabular}{lccc}
\hline \hline & \multicolumn{3}{c}{ Numbers of observations (percent) } \\
\cline { 2 - 4 } Activity & Ashe juniper & Oak $^{1}$ & Other \\
\hline Singing & $664(53.0 \%)$ & $474(37.9 \%)$ & $114(9.1 \%)$ \\
Foraging & $46(26.4 \%)$ & $99(56.9 \%)$ & $29(16.7 \%)$ \\
\hline Quercus durandii brevilobi, Q. texana, Fraximus texensis, and Q. laceviu. \\
: Prumus sp., Ulmus crassifolia. Juglans & sp., Fraximus. Cercis canadensis, etc.
\end{tabular}

contribution to the discrimination of each variable. The high coefficient value for presence of Bigelow oak again suggests importance of this plant species to golden-cheeks.

\section{Vegetation Substrates Used by Golden-cheeks}

A total of 1,252 observations were made on vegetative substrates used for singing by golden-cheek males, while 174 observations were made on foraging substrates (Table 6). Golden-cheeks preferred to sing from the tops of junipers

Table 5. Summary table for discriminant analysis of variables from good and poor golden-cheeked warbler habitats.

\begin{tabular}{|c|c|c|c|}
\hline Variable & Fvalue to enter/remove & Prob. & $\begin{array}{c}\text { Unstandardized } \\
\text { discriminant coefficient }\end{array}$ \\
\hline Presence of Bigelow oak $(Y e s=1 ; N o=0)$ & 13.786 & 0.000 & 2.56221 \\
\hline Distance $(m)$ between trees & 6.201 & 0.011 & 0.00602 \\
\hline Density (stems/ha) of Bigelow oak & 4.294 & 0.033 & -0.00109 \\
\hline Density of Ashe juniper & 7.465 & 0.005 & -0.00049 \\
\hline Height $(\mathrm{cm})$ of stand & 3.182 & 0.062 & -0.02097 \\
\hline Age of Ashe juniper & 2.563 & 0.093 & 0.00165 \\
\hline $\begin{array}{r}\text { Presence of Ashe juniper }(\text { Yes }=1 ; \text { No }=0 \text { ) } \\
\text { Constant }\end{array}$ & 1.760 & 0.162 & $\begin{array}{l}0.53905 \\
-1.71136\end{array}$ \\
\hline
\end{tabular}




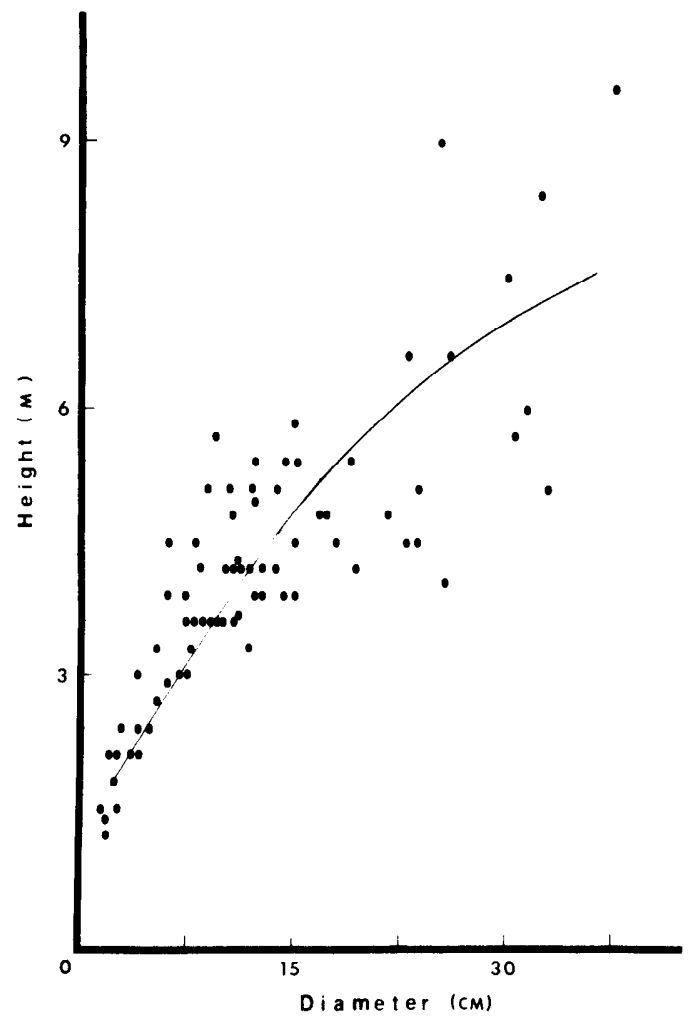

Fig. 6. Relationship between height of Ashe juniper and diameter. $(\mathrm{r}=0.864$; $\left.\mathrm{Y}=1.67 \mathrm{X}^{(10.572}\right)$.

(53.0\% of observations), but foraged primarily in oaks (56.9\% of observations). Lepidoptera larvae inhabiting oaks appear to be an important food source during the first few days after hatching. Indeed, observations of prey taken by golden-cheeks (Table 7) substantiated this observation.

\section{La Esperanza}

On March 20, 1975, I observed 12 golden-cheeks feeding in the low, scrubby brush beneath Ocote pine (Pinus ö̈carpa). These birds were accompanied by several black-throated green, hermit (D. occidentalis), and Townsend's ( $D$. townsendi) warblers, which fed higher in the vegetation (usually within pine canopies). Elevation was about $1,500 \mathrm{~m}$. Excluding pine overstory, the area greatly resembled, physiographically, nesting areas examined at Meridian. Understory was dominated by oaks, $54.6 \%$ of which was encino (Quercus oleoides). Other oak species (=roble) made up an additional $8.1 \%$, while sweetgum (Liquidambar styraciflua) comprised another $21.4 \%$. Pine basal areas averaged $6.5 \pm 3.1 \mathrm{~m}^{2}$, mean tree height was $24.4 \pm 6.8 \mathrm{~m}$, and diameter averaged $44.9 \pm 2.9 \mathrm{~cm}$. Mean understory height was $1.7 \pm 0.6 \mathrm{~m}$. Terrain of the area studied

Table 7. Prey items utilized by golden-cheeked warblers during AprilJune 1975.

\begin{tabular}{lcc}
\hline \hline Prey type & $\begin{array}{c}\text { Number of } \\
\text { observations }\end{array}$ & $\begin{array}{c}\text { Percent } \\
\text { of total }\end{array}$ \\
\hline Insecta & & \\
$\quad$ Lepidoptera & & \\
$\quad$ Larvae & 82 & 53.6 \\
$\quad$ Adults & 1 & 0.6 \\
Orthoptera & 20 & 13.1 \\
Neuroptera & 8 & 5.2 \\
Diptera & 2 & 1.3 \\
Mollusca & 1 & 0.6 \\
Unidentified & 39 & 25.5 \\
\hline
\end{tabular}

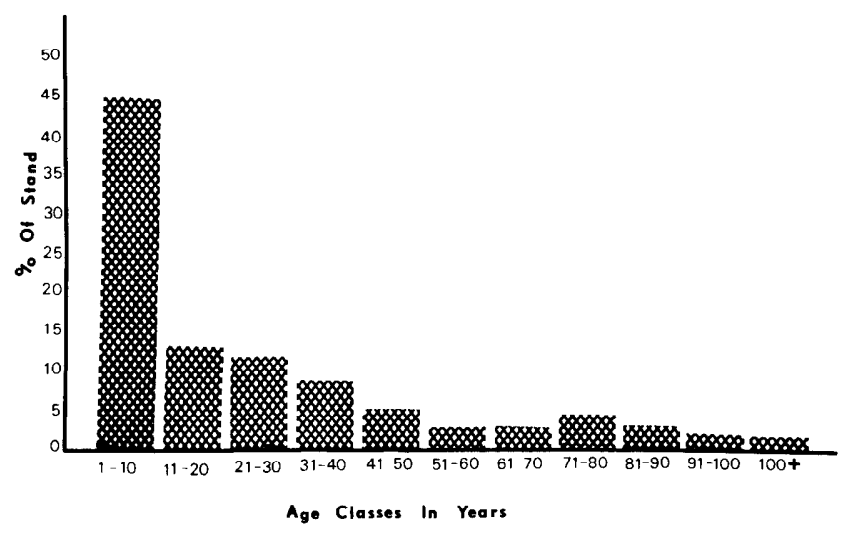

Fig. 7. Age class distribution of Ashe juniper within nesting areas of goldenchecked warblers.

was extremely steep, with numerous small drainages interspersed. The area is currently being manged by foresters from the Corpacion de Hondureña Forestal (COHDEFOR). Consideration for golden-cheek habitat will be incorporated into COHDEFOR policy as their wildlife management program develops.

\section{Discussion}

Nesting Habitat Requirements of the Golden-cheeked Warbler

Golden-cheeks are indeed obligatively dependent on Ashe juniper for nesting materials, but scrub-oak, particularly Bigelow oak, appears to play an equally important role as habitat at Meridian. However, I do not feel that golden-cheeks are totally dependent on Bigelow oak. My observations and those of others (McDonal 1972) suggest that, in other nesting areas (viz., Travis and Medina counties), scrubby forms of species such as Texas oak $(Q$. texana) and live oak $(Q$. virginiana) are also important. In all habitats examined, goldencheeks appear to select areas with a scrubby appearance.

A historical analysis of golden-cheek habitat is enlightening. Juniper-oak is probably the climax community. Before Caucasians settled in Central Texas, large expanses of grassland were maintained as a disclimax by fire (either natural or man-made). Hence, the juniper-oak climax community could only develop among certain refugia such as streams and rocky, limestone outcrops. Golden-cheeks apparently co-evolved as an edge species inhabiting the interface between grassland and juniper-oak. Stands of juniper-oak were probably never extensive. Indeed, Pulich (1976) reported: "Oldtimers related that cedar brakes were restricted to steep slopes and cliffs of limestone canyons and ravines, with a good grass cover on the lower slopes and in between the canyons, in some places to the height of a horse's belly."

My observations, plus historical accounts of original distribution of juniper-oak, contradict assertions by several researchers that golden-cheeks require large blocks, some as great as 2,000 ha, of pure Ashe juniper. Where I have encountered such large homogeneous stands, golden-cheek territories usually occurred along outer edges.

\section{Winter Habitat Requirements}

Pulich (1976) suggested that a study on golden-cheek wintering habitat would be useful in that such a study might identify some "special" factor(s) of wintering habitat which would explain the restricted breeding range. MacArthur (1958) previously noted that winter foraging habitats of warblers were 


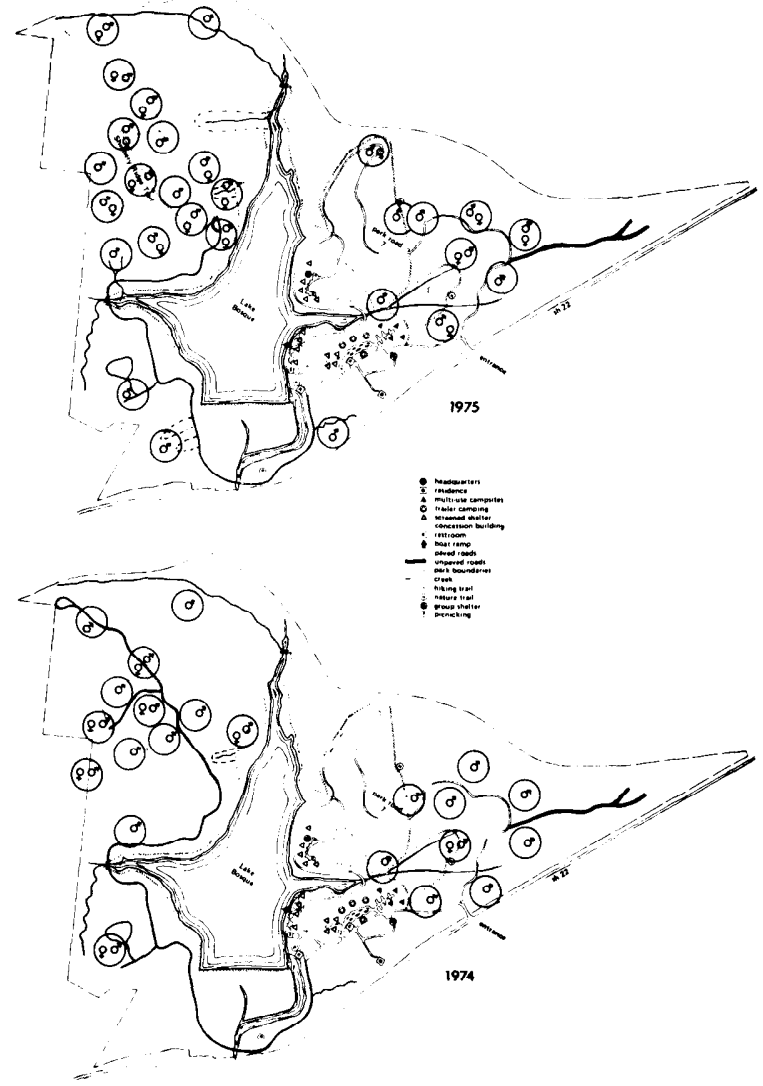

Fig. 8. Locations of golden-cheek male territories during the 1974 and 1975 nesting seasons. Note that location of territories is relatively constant for both years.

structurally similar to those in temperate nesting areas. Although my study on characteristics of winter habitat was limited, I feel that an important habitat component is suggested. I observed golden-cheeks feeding in the same areas as blackthroated green, hermit, and Townsend's warblers. Since these warblers are allopatric for only a short portion of the year, selective pressures on the wintering grounds for resource partitionment must be considerable. Golden-cheeks were feeding in the shrubby understory vegetation, while other warblers, particularly black-throated greens, fed in upper midstory and overstory vegetation. Therefore, it is not surprising that cues for selection of winter habitat may carry over to the breeding season.

\section{Habitat Management}

\section{Evaluation of Nesting Habitat}

Unstandardized discriminant coefficients can be used in evaluating quality of golden-cheek nesting habitat (cf., Conner and Adkisson 1976; Kroll and Whiting 1977). In order to suggest suitability of a particular habitat, the land manager need only establish a habitat sampling scheme which will provide the following data: $(1)$ presence $(=1)$ or absence $(=0)$ of Bigelow oak and Ashe juniper; (2) distance ( $m$ ) between trees; (3) density (stems per hectare) of Bigelow oak and Ashe juniper; (4) height (m) of stand; and, (5) age of Ashe juniper. Then, mean values for each habitat variable must be multiplied by the appropriate discriminant coefficient (Table 5 ) and the products summed. If the total is less than the midpoint value $(0.12427)$, habitat is probably suitable for golden-cheek nesting. Conversely, if the total value is greater than 0.12427 , habitat is probably not adequate. Probability of reaching the correct decision, however, is reflected by the magnitude of the difference between the computed mean and the midpoint value.

\section{Habitat Improvement}

Management objectives for golden-cheeks are certainly compatible with those for both game and livestock production. Large homogeneous blocks of juniper appear to provide neither optimum nesting habitat for the warblers nor adequate forage for deer, turkey, or livestock. Strips of mature ( $\geq 40 \mathrm{yr}$ ) Ashe juniper should be retained along stream and river courses, hill crests, limestone outcrops, and ravines. Width of such strips, based on published territory sizes, should be no less than $75 \mathrm{~m}$. Retention of these strips represents sound range, wildlife, and watershed management.

Large blocks of juniper should be broken up by trails, firebreaks, senderos, and other narrow clearings. Junipers in extremely dense stands must be thinned to promote hardwood growth; juniper-oak ratios should approximate 1.35 to 1 . Growth and spread of scrub oak, particularly Bigelow Oak, can be facilitated by limited shredding and/or light grazing.

\section{Literature Cited}

Carr, A.F. Jr. 1950. Outline for a classification of animal habitat in Honduras. Bull. Amer. Mus. Natur. Hist. 94:563-594.

Conner, R.N., and C.S. Adkisson. 1976. Discriminant function analysis: A possible aid in determining the impact of forest management in woodpecker nesting habitat. Forest. Sci. 22:122-127.

Cottam, G., and J.T. Curtis. 1956. The use of distance measures in phytosociological sampling. Ecology 37:451-460.

Huss, D.L. 1954. Factors influencing plant succession following fire in Ash juniper woodland types in Real County, Texas. Unpub. MS Thesis, Texas A\&M Univ.

Johnston, M.C., W.L. Thompson, and E. Kincaid, Jr. 1952. 16th Breedingbird Census. Aud. Field Notes 6:323-324.

Kroll, J.C., and M.R. Whiting. 1977. Discriminant function analysis of woodcock winter habitat. Proc. Amer. Woodcock Symp., Frederickton, New Brunswick (in press).

MacArthur, F.H. 1958. Population ecology of some warblers of northeastern coniferous forests. Ecology 39:599-619.

McDonal, J.N. 1972. Field Study of the Golden-cheeked Warbler. Unpub. Rep., Dep. Geog. Univ. Texas, Austin.

Monroe, B.L., Jr. 1968. A distributional survey of the birds of Honduras. A.O.U. Monogr. 7.

Nie, N.H., C.H. Hull, J.G. Jenkins, K. Steinbrenner, and D.H. Bent. 1975. Statistical Package for the Social Sciences (2nd ed.). McGraw-Hill, St. Louis.

Pulich, W.M. 1962. In quest of the golden-cheeked warbler. Tex. Orn. Soc. Newsletter 10:5-11.

Pulich, W.M. 1976. The golden-cheeked warbler: A bioecological study. Bull. Texas Parks \& Wildl. Dep.

Shannon, C.E., and W. Weaver. 1963. The Mathematical Theory of Communication. Univ. Ill. Press, Urbana.

$W$ ise, H. 1958. Agricultural possibilities in Honduras. Ceiba 7:1-43. 